\title{
Ozone saturation and decomposition kinetics in porous medium containing different hybrids of maize
}

\author{
Jefferson V. da S. Souza ${ }^{1}$, Ernandes R. de Alencar ${ }^{1}$, Ana M. R. Junqueira ${ }^{1}$ \& Gustavo P. de Oliveira ${ }^{1}$ \\ ${ }^{1}$ Universidade de Brasília/Faculdade de Agronomia e Medicina Veterinária/Programa de Pós-Graduação em Agronomia. Brasília, DF. E-mail: \\ cidadedosol44@gmail.com - ORCID: 0000-0002-4902-7357; ernandesalencar@unb.br (Corresponding author) - ORCID: 0000-0003-4288-4097; \\ anamaria@unb.br - ORCID: 0000-0002-6802-0070; gustavo@unb.br - ORCID: 0000-0003-1449-0066
}

\section{Key words:}

Zea mays

ozonation

saturation concentration

half-life time

\begin{abstract}
A B S T R A C T
The objective of this study was to evaluate ozone saturation and decomposition kinetics in porous medium containing grains of different hybrids of maize. The following hybrids were used: common maize hybrid AG 1051, super sweet maize hybrids Tropical Plus, GSS 42072, GSS 41499 and GSS $41243.1 \mathrm{~kg}$ grain samples with water contents of 13.0\% (w.b.) were placed in glass containers with $3.25 \mathrm{~L}$ capacity. The grains were ozonized at the concentration of $1.28 \mathrm{mg} \mathrm{L}^{-1}$, at $25^{\circ} \mathrm{C}$, with gas flow rate of $5.0 \mathrm{~L} \mathrm{~min}^{-1}$. Saturation time and concentration, half-life time and physical properties such as apparent specific weight, actual specific weight, porosity, sphericity and circularity of each maize hybrid were determined. The experiments were conducted in a completely randomized design with three replicates, using regression analysis of the data. Ozone saturation times remained between 6.6 and $163.9 \mathrm{~min}$, with saturation concentration varying from 0.34 to $1.12 \mathrm{mg} \mathrm{L}^{-1}$. As for the ozone half-life time, the highest value was $10.5 \mathrm{~min}$ for the common maize hybrid AG 1051 and the lowest value was $0.14 \mathrm{~min}$ for the super sweet maize hybrid GSS 41499. It was concluded that ozone saturation and decomposition kinetics in maize depends on the hybrid contained in the porous medium. Ozone decomposition is faster in porous medium containing super sweet maize hybrids compared with the common maize hybrid.
\end{abstract}

Palavras-chave:

Zea mays

ozonização

concentração de saturação

tempo de meia-vida

\section{Saturação e cinética da decomposição de ozônio em meio poroso contendo diferentes híbridos de milho}

\section{R E S U M O}

Objetivou-se neste estudo avaliar a saturação e a cinética de decomposição do ozônio em meio poroso contendo grãos de diferentes híbridos de milho. Foram utilizados híbridos de milho comum, AG 1051, e os de milho super doce, Tropical Plus, GSS 42072, GSS 41499 e GSS 41243. Foram usadas amostras de $1 \mathrm{~kg}$ de milho, com teores de água de 13,0\% (b.u.), acondicionadas em recipientes de vidro com capacidade de 3,25 L. Os grãos foram ozonizados na concentração de $1,28 \mathrm{mg} \mathrm{L}^{-1}$, a $25^{\circ} \mathrm{C}$ e vazão do gás de 5,0 $\mathrm{L} \mathrm{min}^{-1}$. Foram determinados o tempo e a concentração de saturação, o tempo de meia-vida, e as propriedades físicas massa específica aparente, massa específica real, porosidade, esfericidade e circularidade de cada um dos híbridos. O experimento foi realizado com delineamento experimental inteiramente casualizado, com três repetições, utilizando-se análise de regressão dos dados. No que se refere ao tempo de saturação do gás, os valores obtidos permaneceram entre 6,6 e 163,9 min, com concentração de saturação variando de 0,34 a 1,12 $\mathrm{mg} \mathrm{L}^{-1}$. Quanto ao tempo de meia-vida do ozônio, o maior valor obtido foi 10,5 min para o híbrido de milho comum AG 1051 e o menor valor 0,16 min, para o híbrido de milho super doce GSS 41499. Verificou-se que a saturação e cinética de decomposição do ozônio em milho é dependente do híbrido contido no meio poroso. A decomposição do ozônio é mais rápida em meio poroso contendo híbridos de milho super doce. 


\section{INTRODUCTION}

Ozonation has been proposed as an alternative to control grain pests because of the increased resistance of the insects, especially to the phosphine fumigant, and the increase of demand for products free from pesticide residues (Tiwari et al., 2010; Pandiselvam et al., 2015; Xinyi et al., 2017). There are various reports in the literature referring to the effectiveness of ozone in the control of grain pest insects, such as Tribolium castaneum, Sitophilus zeamais, S. oryzae, Oryzaephilus surinamensis Rhyzopertha dominica and larvae of Plodia interpunctella (Kells et al., 2001; Rozado et al., 2008; Sousa et al., 2008; Bonjour et al., 2011; Silva et al., 2016). Ozone has also been used as antimicrobial agent, with proven efficiency in the control of different species of bacteria and fungi (Kim \& Yousef, 2000; Kells et al., 2001; Concha-Meyer et al., 2014; Igura et al., 2004; Hudson \& Sharma, 2009; Alencar et al., 2012; Santos et al., 2016).

Given the expressive applicability of ozone as protecting agent, it is fundamental to study parameters related to the distribution of the gas during grain fumigation, evaluating its saturation and decomposition kinetics in the porous medium. Gaseous ozone has half-life of $20 \mathrm{~min}$ at $20^{\circ} \mathrm{C}$ (Novak \& Yuan, 2007) and rapidly reacts in medium containing organic material, decomposing into oxygen (Cullen et al., 2009). Temperature and moisture content are factors that influence ozone decomposition in porous medium containing grains, as reported by Alencar et al. (2011) and Pandiselvam et al. (2015).

There are few reports on ozone saturation and decomposition in porous medium containing grains (Santos et al., 2007; 2016; Alencar et al., 2011; Pandiselvam et al., 2015; Roberto et al., 2016). For Alencar et al. (2011), parameters related to saturation and decomposition are fundamental to evaluate technical viability and to dimension grain ozonation systems. Due to the differences in chemical composition and physical properties, it is important to study these processes in the different grains. Hence, the present study aimed to evaluate ozone saturation and decomposition kinetics in porous medium with grains of different maize hybrids.

\section{Material AND Methods}

The study was carried out at the Laboratory of Preprocessing and Storage of Vegetal Products, of the College of Agronomy and Veterinary Medicine of the University of Brasília, Brasília-DF, Brazil (15² 45'46.70" S; 470 52' 10.25" W), from January to August 2016.

Ozone gas was obtained using an ozone generator, developed by the company Ozone \& Life, Model O\&L 3.0-O2RM. The ozone generation process used as input oxygen with purity level of approximately $90 \%$, free from moisture, obtained with an oxygen concentrator attached to the generator.

Ozone gas saturation and decomposition kinetics were evaluated using grains from four super sweet maize hybrids (Tropical Plus; GSS 42072; GSS 41499; GSS 41243) and one common maize hybrid (AG 1051), with moisture content around $13 \%$ (w.b.). Ozone concentration was quantified using the iodometric method, described by Clescerl et al. (1999).
Three tests were carried out under the same conditions for each maize hybrid.

Saturation times and the respective saturation concentrations $\left(\mathrm{C}_{\mathrm{Sat}}\right)$ in the evaluation of saturation were determined according to Santos et al. (2007). To measure the ozone gas saturation time in porous medium containing different maize hybrids, the gas was injected at concentration of $1.28 \mathrm{mg} \mathrm{L}^{-1}$, using $3.25 \mathrm{~L}$ glass pots containing $1 \mathrm{~kg}$ of grains (Figure 1 ). It should be noted that the ozone concentration of $1.28 \mathrm{mg} \mathrm{L}^{-1}$ is higher than that used by Rozado et al. (2008), which was efficient to control pest insects of stored maize grains. Input flow rate of $5.0 \mathrm{~L} \mathrm{~min}^{-1}$ of the gas was adopted, at temperature of $25^{\circ} \mathrm{C}$. The residual concentration of the gas was determined after it passed through the product, at regular 5 min intervals, until it remained virtually constant.

To relate ozone gas residual concentration with time, a sigmoid equation was fitted to the obtained data (Eq. 1)

$$
\mathrm{C}=\left[\frac{\mathrm{a}}{1+\mathrm{e}^{-\frac{(\mathrm{t}-\mathrm{b})}{\mathrm{c}}}}\right]
$$

where:

C - ozone gas concentration, $\mathrm{mg} \mathrm{L}^{-1}$;

t - time, min; and,

a, b, c - constants of the equation.

Based on the constants $b$ and $c$ of the fitted equations, it was possible to obtain the ozone saturation times (Eq. 2) in the porous media composed by the different hybrids, as described by Venegas et al. (1998). After the saturation times were determined, the respective saturation concentrations were calculated.

$$
\mathrm{t}_{\mathrm{Sat}}=\mathrm{b}+2 \mathrm{c}
$$

where:

$\mathrm{t}_{\text {Sat }}$ - saturation time, min.

Ozone decomposition kinetics was evaluated after saturation of the porous medium, by quantifying the residual concentration through the iodometric method, after different time intervals during which the gas was not injected and spontaneous decomposition occurred, following the methodology adopted by Santos et al. (2007).

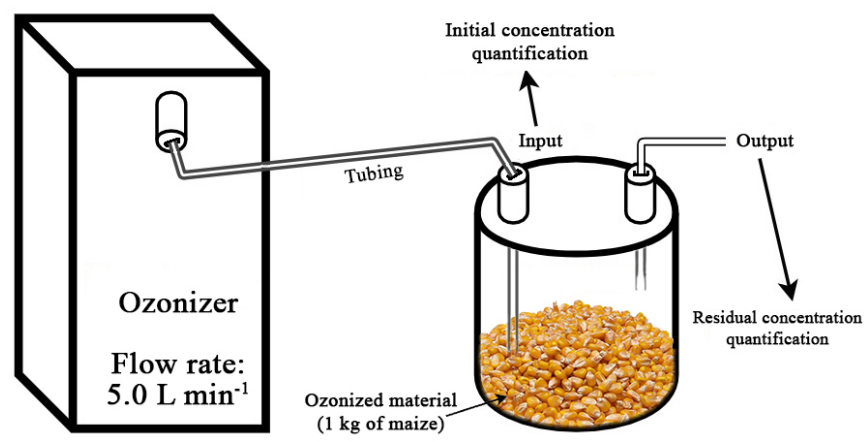

Figure 1. Scheme of maize ozonation and quantification of gas concentration 
In the quantification of residual ozone, after the different rest periods, atmospheric air was injected at rate of $1.0 \mathrm{~L} \mathrm{~min}^{-1}$. The first-order kinetic model (Eq. 3) was fitted to the data of ozone residual concentration as a function of the different time intervals (Wright, 2004). The decomposition kinetics model, after linearization (Eq. 4), was fitted through regression analysis. The decomposition rate constant $(\mathrm{k})$ is given by the slope of the line after fitting the integrated and linearized models.

$$
\begin{gathered}
\frac{\mathrm{dC}}{\mathrm{dt}}=-\mathrm{kC} \\
\ln \mathrm{C}=\ln \mathrm{C}_{0}-\mathrm{kt}
\end{gathered}
$$

where:

$$
\begin{array}{ll}
\mathrm{C} & \text { - ozone gas concentration, } \mathrm{mg} \mathrm{L}^{-1} ; \\
\mathrm{t} & \text { - time, min; } \\
\mathrm{k} & \text { - decomposition rate constant, } \mathrm{min}^{-1} \text {; and, } \\
\mathrm{C}_{0} & \text { - ozone gas saturation concentration, } \mathrm{mg} \mathrm{L}^{-1} \text {. }
\end{array}
$$

Decomposition rate constants were used to calculate the half-life time $\left(t_{1 / 2}\right)$ of ozone in porous medium containing different maize hybrids, which is defined by Eq. 5 (Wright, 2004) for the first-order kinetics model:

$$
\mathrm{t}_{1 / 2}=\frac{\ln 2}{\mathrm{k}}
$$

Additionally, the following physical properties of the different hybrids were determined: apparent specific weight, actual specific weight, porosity, circularity and sphericity. Apparent specific weight $(\rho)$ was determined based on the relationship between weight and volume occupied by maize grains, whereas the actual specific weight $\left(\rho_{\mathrm{r}}\right)$ was obtained according to Moreira et al. (1985). After determining apparent specific weight and actual specific weight, porosity $(\mathrm{P})$ was calculated using Eq. 6.

$$
\mathrm{P}=1-\frac{\rho}{\rho_{\mathrm{r}}}
$$

Sphericity and circularity were determined as defined by Mohsenin (1986), using Eqs. 7 and 8, by measuring the dimensions of 50 grains of each maize hybrid using a caliper.

$$
\begin{gathered}
\varnothing=\left[\frac{(\mathrm{a} \mathrm{b} \mathrm{c})^{\frac{1}{3}}}{\mathrm{a}}\right] 100 \\
C=100\left(\frac{\mathrm{di}}{\mathrm{dc}}\right)
\end{gathered}
$$

where:

$\varphi \quad$ - sphericity, \%;

a - largest characteristic dimension of the grain, $\mathrm{mm}$;

b - mean characteristic dimension of the grain, $\mathrm{mm}$; c - lower characteristic dimension of the grain, $\mathrm{mm}$;

C - circularity, \%;

di - diameter of the largest circle inscribed, $\mathrm{mm}$; and,

$\mathrm{dc}$ - diameter of the largest circle circumscribed, $\mathrm{mm}$.

The experiment was conducted in a completely randomized design, in triplicate, using data regression analysis. The software SigmaPlot 10.0 was used to obtain the regression equations and plot the graphs, referring to the processes of saturation and decomposition kinetics.

\section{Results AND Discussion}

For the saturation time, the values remained within the range from 6.5 to $163.9 \mathrm{~min}$, and the highest value was obtained for the hybrid GSS 41499 (Table 1 and Figure 2). The ozone gas saturation concentration varied from 0.34 and $1.12 \mathrm{mg} \mathrm{L}^{-1}$, and highest value was obtained for the common maize hybrid AG 1051, equivalent to $87.5 \%$ of the initial concentration, with saturation time of $6.5 \mathrm{~min}$. On the other hand, for the super

Table 1. Fitted regression equations and the respective coefficients of determination $\left(r^{2}\right)$ for ozone residual concentration $\left(\mathrm{mg} \mathrm{L}^{-1}\right)$ during the saturation of porous medium containing different maize hybrids, with initial gas concentration of $1.28 \mathrm{mg} \mathrm{L}^{-1}$

\begin{tabular}{lcccc}
\hline Maize variety & Fitted equations & $\mathbf{r}^{2}$ & $\begin{array}{c}\mathbf{t}_{\text {sat }} \\
(\mathbf{m i n})\end{array}$ & $\begin{array}{c}\mathbf{C}_{\text {sat }} \\
\left(\mathbf{m g ~ L}^{-1}\right)\end{array}$ \\
AG 1051 & $\hat{y}=\frac{1.27}{1+\mathrm{e}^{-\left(\frac{x-3.47}{1.50}\right)}}$ & 0.95 & 6.5 & 1.12 \\
Tropical Plus & $\hat{y}=\frac{0.77}{1+e^{-\left(\frac{x-31.48}{10.45}\right)}}$ & 0.95 & 52.4 & 0.68 \\
GSS 41499 & $\hat{y}=\frac{0.39}{1+e^{-\left(\frac{x-145.47}{9.29}\right)}}$ & 0.99 & 163.9 & 0.34 \\
GSS 42072 & $\hat{y}=\frac{0.41}{1+e^{-\left(\frac{x-103.13}{8.33}\right)}}$ & 0.99 & 119.8 & 0.36 \\
\hline GSS 41243 & $\hat{y}=\frac{0.95}{1+e^{-\left(\frac{x-35.98}{26.67}\right)}}$ & 0.93 & 88.4 & 0.83 \\
\hline
\end{tabular}

$\mathrm{t}_{\text {Sat }}-$ Saturation time; $\mathrm{C}_{\text {Sat }}-$ Saturation concentration

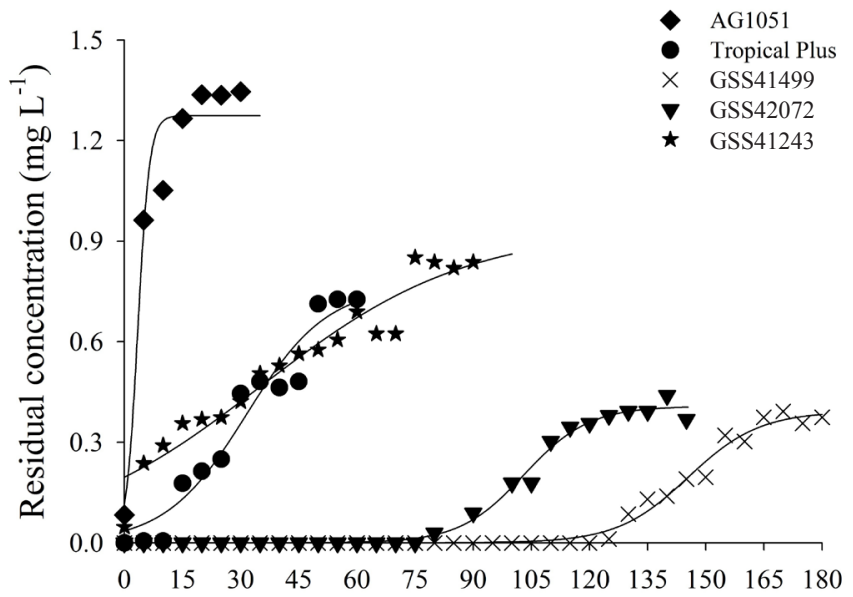

Ozonation period ( $\mathrm{min})$

Figure 2. Residual ozone concentration over time in porous medium containing grains of different maize hybrids, with initial gas concentration of $1.28 \mathrm{mg} \mathrm{L}^{-1}$ 
sweet maize hybrid GSS 41499, the saturation concentration was equivalent to $26.6 \%$ of the initial concentration, associated with the longest saturation time, equal to $163.9 \mathrm{~min}$.

The observed behavior, regarding the saturation of porous medium containing grains of different maize hybrids, was consistent with Strait (1998), Kells et al. (2001) and Mendez et al. (2003), who claimed that ozone behavior during grain fumigation has two distinct phases. These authors claim that the grains have active sites on their surface that react with ozone during the initial fumigation, leading to degradation of the gas and, consequently, the elimination of these sites (phase I). Once these sites have reacted with ozone (phase 2), its degradation rate decreases.

Ozone decomposition (Figure 3 and Table 2) was more accelerated in the super sweet maize hybrids GSS 42072 and GSS 41499, with decomposition rate constants (k) of 0.835 and $4.471 \mathrm{~min}^{-1}$, respectively. It should be pointed out that the $\mathrm{k}$ value in the porous medium containing grains of the

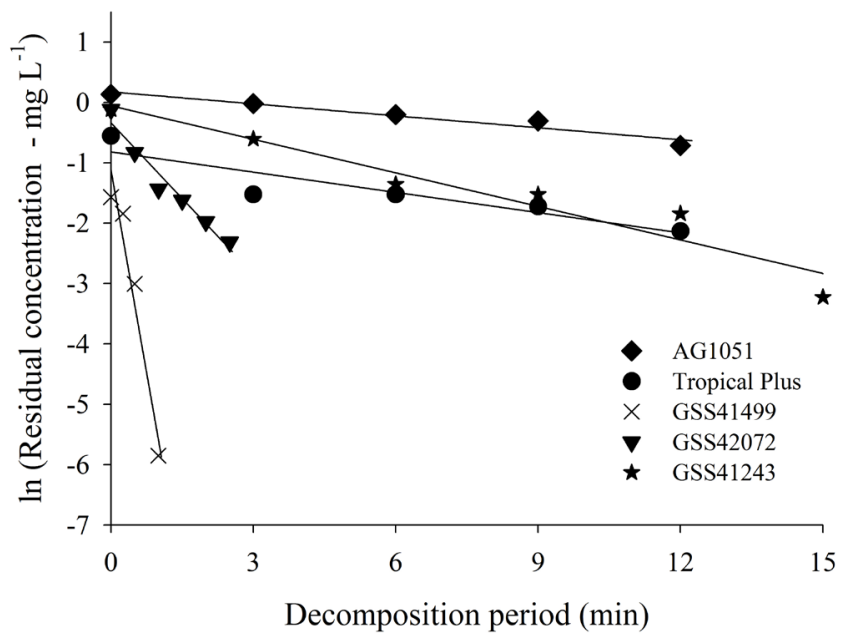

Figure 3. First-order kinetic model fitted to the observed data of ozone residual concentration in porous medium containing different maize hybrids at temperature of $25^{\circ} \mathrm{C}$

Table 2. Regression equations over time for residual concentration of ozone gas in porous medium containing grains of different maize hybrids, at temperature of $25^{\circ} \mathrm{C}$ and the respective coefficients of determination $\left(r^{2}\right)$ and half-life times

\begin{tabular}{lccc}
\hline Maize hybrids & Fitted equations & $\mathbf{r}^{2}$ & $\begin{array}{c}\text { Half-life times } \\
(\mathbf{m i n})\end{array}$ \\
AG 1051 & $\hat{y}=0.174-0.066^{*} \times$ & 0.94 & 10.50 \\
Tropical Plus & $\hat{y}=-0.821-0.110^{*} x$ & 0.84 & 6.30 \\
GSS 41499 & $\hat{y}=-1.111-4.471^{*} x$ & 0.94 & 0.16 \\
GSS 42072 & $\hat{y}=-0.339-0.835^{*} x$ & 0.96 & 0.80 \\
GSS 41243 & $\hat{y}=-0.057-0.185^{*} x$ & 0.92 & 3.80 \\
\hline
\end{tabular}

*Significant at 0.05 probability levels by $F$ test hybrid GSS 41499 is 5.3 times higher than that for the hybrid GSS 42072. Lower decomposition rates were observed in the hybrids AG 1051, Tropical Plus and GSS 41243, with values of $0.066,0.110$ and $0.185 \mathrm{~min}^{-1}$, respectively.

For ozone half-life time (Table 2), highest values were found for the hybrids AG 1051 and Tropical Plus, equivalent to 10.5 and $6.3 \mathrm{~min}$, respectively. The lowest values of half-life time were obtained for grains of the hybrids GSS 41499 and GSS 42072, which stand out for having longer saturation time, as demonstrated in Table 1. Ozone half-life times obtained in the present study were lower than those found in the absence of biological material (20 to $50 \mathrm{~min}$ ), as well as in aqueous solutions (20 to $30 \mathrm{~min}$ ) (Khadre et al., 2001), confirming the influence of medium composition on gas reactivity. Santos et al. (2007) studied ozone decomposition kinetics in common maize, using the concentration of $100 \mathrm{ppm}\left(\approx 0.21 \mathrm{mg} \mathrm{L}^{-1}\right)$. These authors found half-life time of $5.57 \mathrm{~min}$, a behavior similar to that observed in the hybrid Tropical Plus. In porous medium containing peanut with $7.1 \%$ water content at $25^{\circ} \mathrm{C}$, Alencar et al. (2011) obtained half-life time equivalent to $7.7 \mathrm{~min}$, which is higher than those for all hybrids of super sweet maize, but lower than that of the common maize hybrid.

Expressive differences were found in the saturation and decomposition of ozone gas, between the different maize hybrids. Such differences are possibly associated with the physical properties of the grains. Table 3 shows the data referring to apparent specific weight, actual specific weight, porosity, sphericity and circularity of the different maize hybrids. The highest values of saturation time associated with lower values of saturation concentration were obtained in super sweet maize hybrids. In general, super sweet maize hybrids showed the lowest values of apparent specific weight and actual specific weight, and highest values of porosity, sphericity and circularity, compared with the common maize hybrid (AG1051). The literature has data related to other types of grains and reports that the observed differences may be related to physical properties. For peanut grains, Alencar et al. (2011) observed saturation time and concentration equivalent to $175 \mathrm{~min}$ and $0.26 \mathrm{mg} \mathrm{L}^{-1}$, respectively, for grains with water content of $7.1 \%$, initial gas concentration of $0.45 \mathrm{mg} \mathrm{L}^{-1}$, at $25{ }^{\circ} \mathrm{C}$. Santos et al. (2016) studied the saturation process in porous medium containing rice grains, adopting flow rate of $1.0 \mathrm{~L} \mathrm{~min}^{-1}$ and concentration of $10.13 \mathrm{mg} \mathrm{L}^{-1}$, and observed saturation time and concentration of $13.97 \mathrm{~min}$ and $5.00 \mathrm{mg} \mathrm{L}^{-1}$, respectively.

In addition, the difference in the chemical composition of the hybrids may possibly have affected the processes of ozone saturation and decomposition. According to Tiwari et al. (2010), ozone diffusion depends on the chemical composition of the

Table 3. Mean values of apparent specific weight $\left(\mathrm{kg} \mathrm{m}^{-3}\right)$, actual specific weight $\left(\mathrm{g} \mathrm{cm}^{-3}\right)$, porosity $(\%)$, sphericity $(\%)$ and circularity (\%) of the different maize hybrids

\begin{tabular}{|c|c|c|c|c|c|}
\hline \multirow{2}{*}{ Maize hybrid } & \multicolumn{2}{|c|}{ Specific weight } & Porosity & Sphericity & Circularity \\
\hline & Apparent $\left(\mathrm{kg} \mathrm{m}^{-3}\right)$ & Actual $\left(\mathrm{g} \mathrm{cm}^{-3}\right)$ & & $(\%)$ & \\
\hline AG1051 & $763.4 \pm 3.9$ & $1,160.2 \pm 3.9$ & $35.5 \pm 0.2$ & $59.9 \pm 5.7$ & $56.5 \pm 3.7$ \\
\hline Tropical Plus & $442.8 \pm 1.8$ & $897.9 \pm 17.4$ & $50.7 \pm 1.2$ & $86.1 \pm 8.1$ & $68.9 \pm 6.4$ \\
\hline GSS 41499 & $533.2 \pm 4.0$ & $1,019.2 \pm 18.6$ & $47.7 \pm 1.2$ & $86.2 \pm 10.4$ & $85.6 \pm 6.8$ \\
\hline GSS 42072 & $561.7 \pm 5.1$ & $1,021.2 \pm 18.2$ & $45.7 \pm 1.1$ & $89.1 \pm 9.1$ & $87.6 \pm 6.2$ \\
\hline GSS 41243 & $542.2 \pm 2.8$ & $1,028.2 \pm 4.9$ & $47.3 \pm 0.3$ & $82.5 \pm 11.7$ & $82.1 \pm 7.6$ \\
\hline
\end{tabular}


medium because this gas reacts with the chemical constituents present in its external layer. It should be highlighted that sweet maize differs from common maize due to the high sugar content and low starch content (Araújo et al., 2001). While super sweet maize has approximately $25 \%$ sugar and $15-25 \%$ starch, common maize has approximately $3 \%$ sugar and $60-70 \%$ starch (Pereira Filho et al., 2003). Future studies that can elucidate the influence of physical properties and chemical composition are fundamental to implement ozonation as a technique of maize grain conservation during storage.

\section{Conclusions}

1. Ozone saturation and decomposition kinetics in maize grains depend on the hybrid contained in the porous medium.

2. The saturation process is slower in super sweet maize hybrids, with lower values of saturation concentration and higher values of saturation time, compared with common maize hybrids.

3. Ozone decomposition is faster in porous medium containing super sweet maize grains, compared with common maize grains.

\section{Literature Cited}

Alencar, E. R. de; Faroni, L. R. D.; Martins, M. A.; Costa, A. R. da; Cecon, P. R. Decomposition kinetics of gaseous ozone in peanuts. Engenharia Agrícola, v.31, p.930-939, 2011. https://doi. org/10.1590/S0100-69162011000500011

Alencar, E. R. de; Faroni, L. R.; Soares, N. de F.; Silva, W. A. da; Carvalho M. C. Efficacy of ozone as a fungicidal and detoxifying agent of aflatoxins in peanuts. Journal of the Science of Food and Agriculture, v.92, p.899-905, 2012. https://doi.org/10.1002/ jsfa.4668

Araújo, E. F.; Corrêa, P. C.; Silva, R. F. da. Comparação de modelos matemáticos para descrição das curvas de dessorção de sementes de milho-doce. Revista Pesquisa Agropecuária Brasileira, v.36, p.991-995, 2001. https://doi.org/10.1590/S0100204X2001000700009

Bonjour, E. L.; Opit, G. P.; Hardin, J.; Jones, C. L.; Payton, M. E.; Beeby, R. L. Efficacy of ozone fumigation against the major grain pests in stored wheat. Journal of Economic Entomology, v.104, p.308-316, 2011. https://doi.org/10.1603/EC10200

Clescerl, L. S.; Greenberg, A. E.; Eaton, A. D. Standard methods for the examination of water and wastewater. 20.ed. Denver: American Water Works Association, 1999. 1325p.

Concha-Meyer, A.; Eifert, J.; Williams, R.; Marcy, J.; Welbaum, G. Survival of Listeria monocytogenes on fresh blueberries (Vaccinium corymbosum) stored under controlled atmosphere and ozone. Journal of Food Protection, v.77, p.832-836, 2014. https:// doi.org/10.4315/0362-028X.JFP-13-441

Cullen, P. J.; Tiwari, B. K.; O’Donnell, C. P.; Muthukumarappan, K. Modelling approaches to ozone processing of liquid foods. Trends in Food Science \& Technology, v.20, p.125-136, 2009. https://doi. org/10.1016/j.tifs.2009.01.049

Hudson, J. B.; Sharma, M. The practical application of ozone gas as an anti-fungal (anti-mold) agent. Ozone: Science \& Engineering, v.31, p.326-332, 2009. https://doi.org/10.1080/01919510903043996
Igura, N.; Fujii, M.; Shimoda, M.; Hayakawa, I. Inactivation efficiency of ozonated water for Fusarium oxysporum conidia under hydroponic greenhouse conditions. Ozone: Science \& Engineering, v.26, p.217-221, 2004. https://doi.org/10.1080/01919510490507937

Kells, S. A.; Mason, L. J.; Maier, D. E.; Woloshuk, C. P. Efficacy and fumigation characteristics of ozone in stored maize. Journal of Stored Products Research, v.37, p.371-383, 2001. https://doi. org/10.1016/S0022-474X(00)00040-0

Khadre, M. A.; Yousef, A. E.; Kim, J. G. Microbiological aspects of ozone applications in food: A review. Journal of Food Science, v.66, p.1242-1252, 2001. https://doi.org/10.1111/j.1365-2621.2001. tb15196.x

Kim, J.-G.; Yousef, A. E. Inactivation kinetics of foodborne spoilage and pathogenic bacteria by ozone. Journal of Food Science, v.65, p.521-528, 2000. https://doi.org/10.1111/j.1365-2621.2000. tb $16040 . x$

Mendez, F.; Maier, D. E.; Mason, L. J.; Woloshuk, C. P. Penetration of ozone into columns of stored grains and effects on chemical composition and performance. Journal of Stored Products Research, v.39, p.33-44, 2003. https://doi.org/10.1016/S0022474X(02)00015-2

Mohsenin, N. N. Physical properties of plant and animal materials. 2.ed. Amsterdam: Gordon and Breach Gordon and Breach Publishers, 1986. 841p.

Moreira, S. M. C.; Chaves, M. A.; Oliveira, L. M. Comparação da eficiência de líquidos na determinação da massa específica aparente de grãos agrícolas. Revista Brasileira de Armazenamento, v.9, p.22-24, 1985.

Novak, J. S.; Yuan, J. T. C. The ozonation concept: Advantages of ozone treatment and commercial developments. In: Tewari, G.; Juneja, V. K. (ed). Advances in thermal and non-thermal food preservation. Ames: Blackwell Publishing, 2007. Chap.7, p.185-193. https://doi. org/10.1002/9780470277898.ch10

Pandiselvam, R.; Thirupathi, V.; Anandakumar, S. Reaction kinetics of ozone gas in paddy grains. Journal of Food Process Engineering, v.38, p. 594-600, 2015. https://doi.org/10.1111/jfpe.12189

Pereira Filho, I. A.; Cruz, J. C.; Gama, E. E. G. Cultivares para o consumo verde. In: Pereira Filho, I. A. O cultivo do milho verde. Brasília: Embrapa Milho e Sorgo, 2003. Cap.1, p.17-30.

Roberto, M. de A.; Alencar, E. R. de; Ferreira, W. F. de S.; Mendonça, M. A; Alves, H. Saturação do ozônio em coluna contendo grãos de amendoim e efeito na qualidade. Brazilian Journal of Food Technology, v.19, p.1-8, 2016. https://doi.org/10.1590/19816723.5115

Rozado, A. F.; Faroni, L. R. D.; Urruchi, W. M. I.; Guedes, R. N. C.; Paes, J. L. Aplicação de ozônio contra Sitophilus zeamais e Tribolium castaneum em milho armazenado. Revista Brasileira de Engenharia Agrícola e Ambiental, v.12, p.282-285, 2008. https:// doi.org/10.1590/S1415-43662008000300009

Santos, J. E.; Martins, M. A.; Faroni, L. R. D.; Andrade, M. P.; Carvalho, M. C. S. Ozonization process: Saturation time, decomposition kinectis and quality of maize grains (Zea mays L.). In: IOA Conference and Exhibition, 2007, Valência. Proceedings... Valência: International Ozone Association, 2007.

Santos, R. R.; Faroni, L. R. D.; Cecon, P. R.; Ferreira, A. P. S.; Pereira, O. L. Ozone as fungicide in rice grains. Revista Brasileira de Engenharia Agrícola e Ambiental, v.20, p.230-235, 2016. https:// doi.org/10.1590/1807-1929/agriambi.v20n3p230-235 
Silva, G. N.; Faroni, L. R. D.; Cecon, P. R.; Sousa, A. H. de; Heleno, F. F. Ozone to control Rhyzopertha dominica (Coleoptera: Bostrichidae) in stored wheat grains. Journal of Stored Products and Postharvest Research, v.7, p.37-44, 2016.

Sousa, A. H.; Faroni, L. R. D. ; Guedes, R. N. C.; Tótola, M. R.; Urruchi, W. I. Ozone as a management alternative against phosphine-resistant insect pests of stored products. Journal of Stored Products Research, v.44, p.379-385, 2008. https://doi. org/10.1016/j.jspr.2008.06.003

Strait, C. A. Efficacy of ozone to control insects and fungi in stored grain. West Lafayette: Purdue University, 1998. 59p. Dissertation Master
Tiwari, B. K.; Brennan, C. S.; Curran, T.; Gallagher, E.; Cullen, P. J.; O'Donnell, C. P. Application of ozone in grain processing. Journal of Cereal Science, v.51, p.248-255, 2010. https://doi.org/10.1016/j. jcs.2010.01.007

Venegas, J. G.; Harris, R. S.; Simon, B. A. A comprehensive equation for the pulmonary pressure-volume curve. Journal of Applied Physiology, v.84, p.389-395, 1998. https://doi.org/10.1152/jappl.1998.84.1.389

Wright, M. R. An introduction to chemical kinetics. 1.ed. New York: John Wiley \& Sons, 2004. 441p. https://doi.org/10.1002/047009060X

Xinyi, E.; Subramanyam, B.; Li, B. Efficacy of ozone against phosphine susceptible and resistant strains of four stored-product insect species. Insects, v.8, p.1-14, 2017. 